\title{
Wood-boring bivalves and boring linings
}

\author{
SIÂN EVANS
}

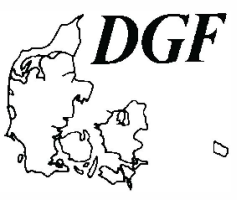

Evans, S. Wood-boring bivalves and boring linings. Bulletin of the Geological Society of Denmark, Vol. 45, pp. 130-134. Copenhagen, 1999-01-30. https://doi.org/10.37570/bgsd-1998-45-14

The anatomical features and morphology and lining of the borings of woodboring bivalves are evaluated as taxobases. The aragonitic valves and pallets have poorer preservation potential than the calcitic boring linings that some forms secrete. These linings may be septate, containing retrusive caps.

Key words: Wood-boring bivalves, Teredinidae, Xylophagainae, Cretaceous, boring lining, taxonomy.

S. Evans, Department of Palaeontology, The Natural History Museum, London SW7 5DB, U.K. 2 August 1998.

The dominant agents of wood bioerosion throughout the Mesozoic and Cenozoic are pholadacean boring bivalves. The Pholadacea comprise two families (Turner 1969), the Teredinidae (shipworms) and the Pholadidae (piddocks). The wood-boring habit occurs in both families, but the most specialized, diverse and successful wood-borers are teredinids. Extant teredinids have so derived a morphology that their relationships with other members of the Pholadacea are poorly understood (Hoagland \& Turner 1981). A detailed understanding of fossil wood-borers may yield the evidence necessary to elucidate the evolution of this economically important group. However, identification of fossil pholadaceans is complicated by stenomorphism and non-preservation of critical taxonomic characters (Turner 1969).

\section{Pholadacea}

The Pholadacea are a highly specialized group, adapted to boring into relatively hard substrata. They are probably mechanical borers (Röder 1977), although Morton (1983) suggests that chemical boring may occur in some genera.

\section{Teredinidae}

The Teredinidae (Fig. 1F) are, with the exception of one genus, obligate wood-borers, able to digest cellulose excavated from the substrate during boring
(Waterbury et al. 1983). Their valves are highly reduced in size, hemispherical in shape and, like some other pholadacean groups, bear an internal, rod-like projection, the apophysis (Fig. 1F). Valve shape is extremely conservative within the family and is of limited use in taxonomy (Turner 1966). Instead, unique structures, calcareous pallets which are secreted at the distal end of the siphons, are used to distinguish genera and species. The pallet is forced against a calcareous lining at the aperture of the boring to produce a seal (Fig. 2A). The apertural lining is secreted early in the ontogeny of the individual and may be extended during life. After the cessation of boring the lining may be completed around the outside of the shells to produce a closed tube (Huggett \& Gale 1995, Savrda \& Smith 1996).

\section{Pholadidae}

The Pholadidae bore into a range of substrates, including wood, mud and relatively hard rock. In addition to the valves, calcareous accessory plates are produced in regions where the soft parts are not protected by the valves, for example the pedal gape. These plates perform a similar function to the teredinid tube in that they protect the bivalve within the substrate. The accessory plates, rather than the valves themselves, are the major basis for all levels of taxonomy within the Pholadidae (Turner 1954, 1955).

The wood-boring habit occurs in two pholadid subfamilies, the Martesiinae and the Xylophagainae 


Martesiinae $\quad$ Xylophagainae
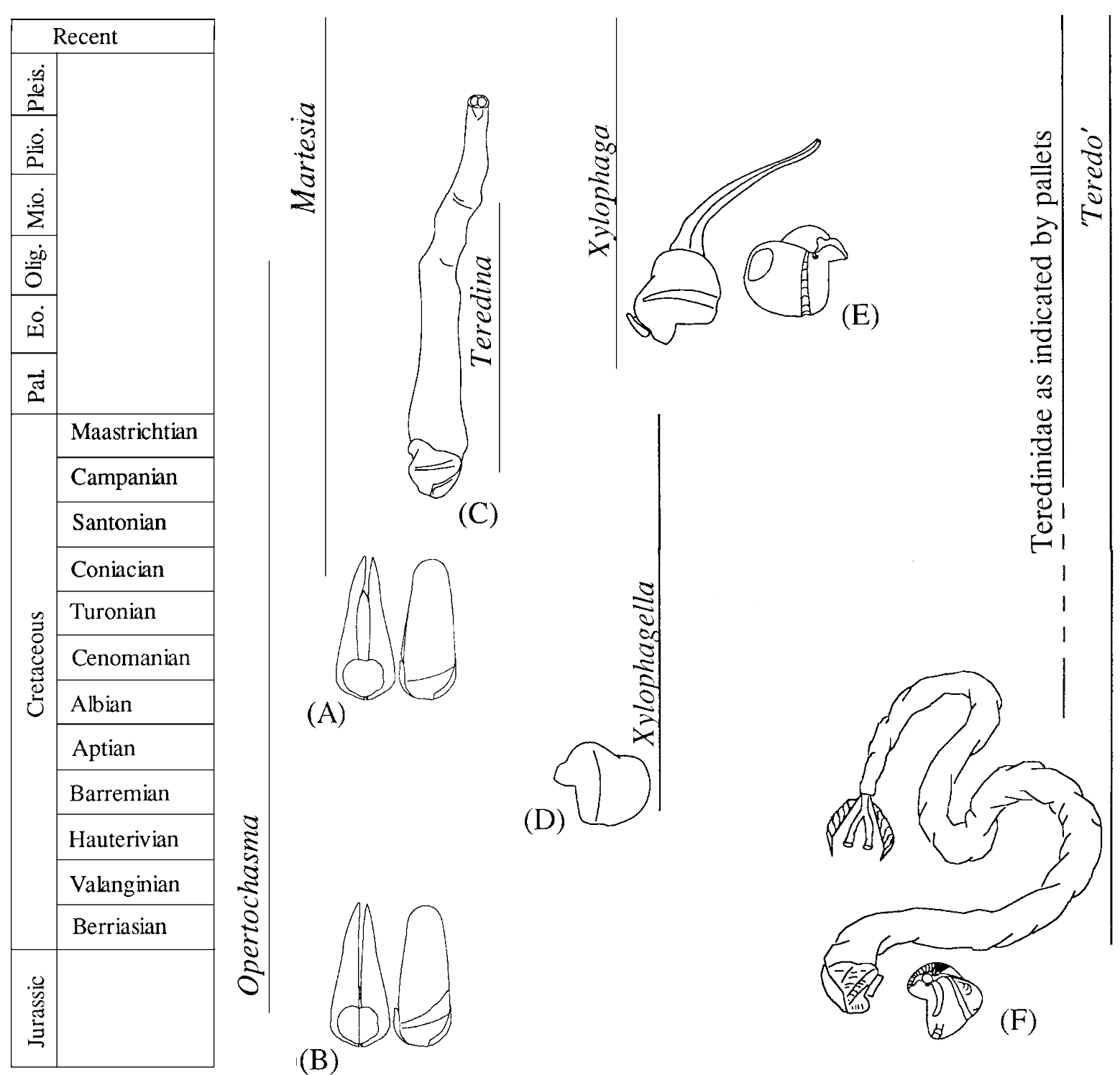

(B)

(D)<smiles>C1#CC(C2CCCCC2)C#C1</smiles>
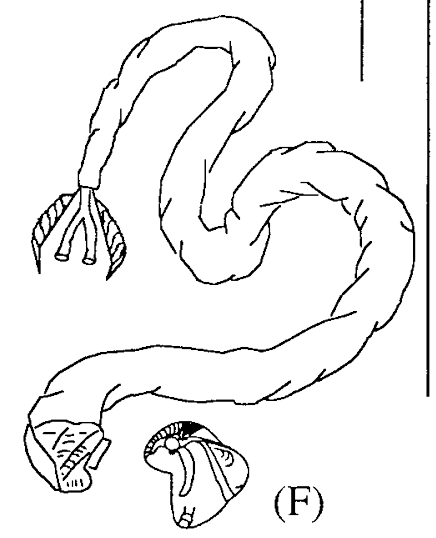

Fig. 1. Geological ranges and morphologies of the major groups of wood-boring bivalves. (A) Martesia (Martesiinae), with distinctive accessory plates that characterize the subfamily. (B) Opertochasma (Martesiinae). (C) Teredina (Martesiinae). The valves and accessory plates are fused together internally to produce the tube. (D) Xylophagella (?Xylophagainae). External view of valve, mesoplax and apophysis unknown. (E) Xylophaga (Xylophagainae). Left overall view showing soft anatomy, valve and single dorsal accessory plate; right - inner view of the valve which lacks an apophysis. (F) Bankia (Teredinidae). Left - overall view showing soft anatomy, valve and pallets; right - inner view of valve showing the apophysis. 
(A) Teredolites clavatus

Formed by a pholadid e.g. Martesia

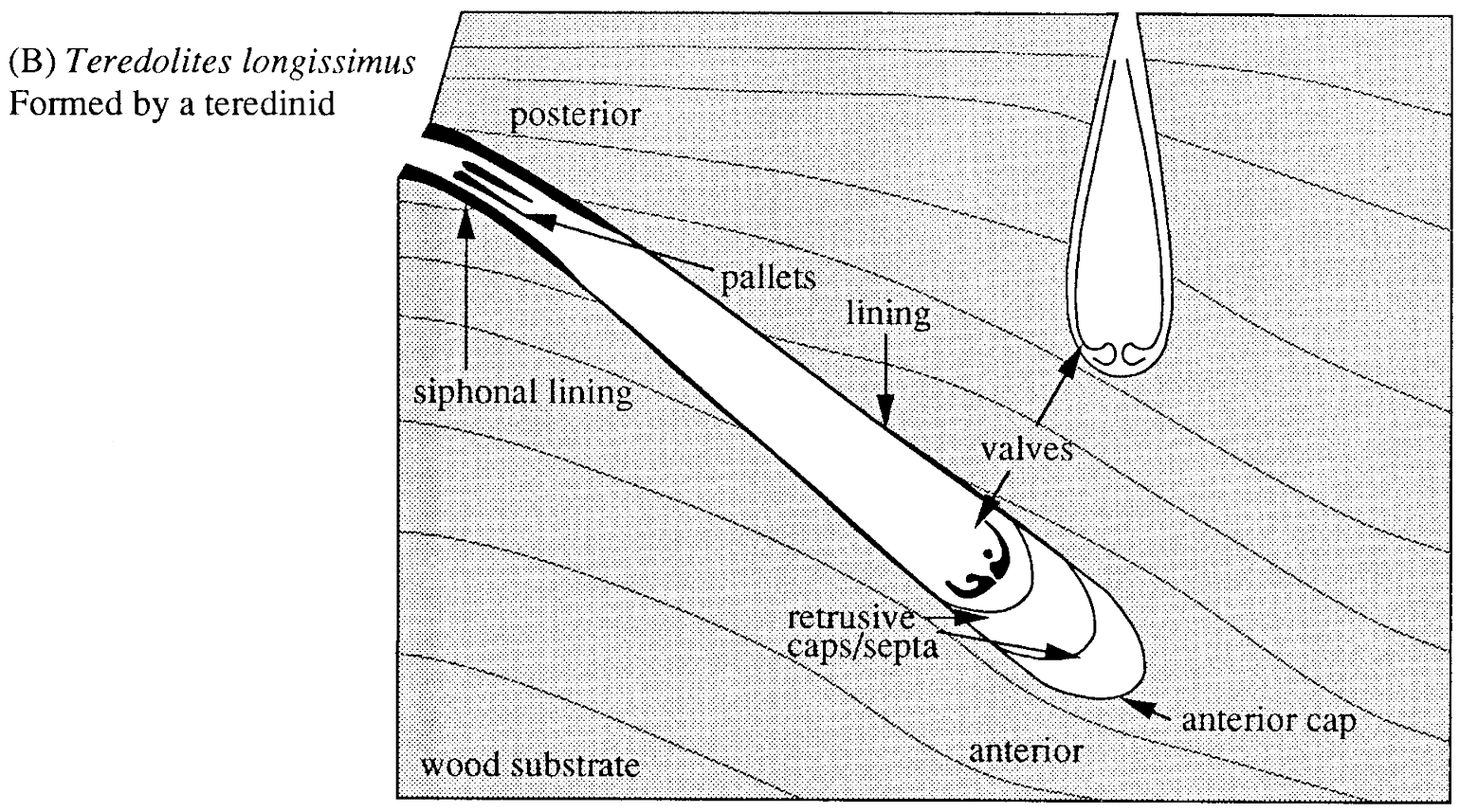

Fig. 2. Borings in wood, Teredolites Leymerie, 1842. (A) T. clavatus Leymerie, 1842, clavate Teredolites predominantly perpendicular to the wood grain, having a length/width ratio less than 5. (B) T. longissimus Kelly \& Bromley, 1984, clavate Teredolites predominantly parallel to the wood grain, having a length/width ratio greater than 5 . When formed by teredinids, the boring lining may be distinctive, with retrusive caps and a thickened siphonal region. This ichnospecies may also be formed by xylophagaines.

(Turner 1969). Martesia (Fig. 1A) produces dwelling traces almost exclusively in wood and is a significant economic threat to wooden structures in the marine environment. The Martesiinae produce a number of characteristic accessory plates, and the valves bear the apophysis also seen in the Teredinidae. Many extinct wood-boring taxa, such as Opertochasma (Fig. 1B) and Teredina (Fig. 1C), have been assigned to this subfamily (Turner 1969).

The Xylophagainae (Fig. 1E) are highly specialised deep-sea wood-borers, probably capable of cellulose digestion (Turner 1973). The valves are very similar to those of teredinids, but possess a single, dorsal accessory plate (mesoplax), and lack apophyses. Purchon (1941) believed that the Xylophagainae and the Teredinidae shared a common wood-boring ancestor within the Pholadacea. However, Turner (1977), on the basis of electrophoretic analysis, concluded that the Xylophagainae are no more closely related to the Teredinidae than they are to the Martesiinae. The weight of evidence suggests that the Teredinidae and the Xylophagainae originated independently and similarities between the groups are the result of convergence (Turner 1972, 1977, 1981).

\section{Fossil teredinids}

The activities of fossil wood-borers may be inferred from their preserved shells and characteristic trace fossils. Modern pholads are easily distinguished; pholadids possess accessory plates and teredinids possess pallets. In contrast, recognizing fossils, particularly xylophagaines and teredinids, can be extremely difficult, since the characteristic structures may be obscured or not preserved (Turner 1969).

Elongate borings in Cretaceous wood have been attributed to the activities of 'Teredo'. However, most shells associated with such borings have been assigned members of the Xylophagainae (e.g., Kelly 1988). Unequivocal evidence of the family Teredinidae sensu stricto - the presence of pallets - has only been recorded from the Tertiary (Elliot 1963, Cvancara 1965, 1970). Undescribed Cretaceous pallets from the Blackdown Greensand of southern England (Kelly 1988) extend the fossil record of the family back to the Albian (Lower Cretaceous). Except for the isolated occurrences of Cretaceous pallets, very little is known of the pre-Cenozoic history of the teredinids.

Where pallets and accessory plates are not preserved, the overall shell shape tends to be used to identify 
fossil wood-borers. Modern xylophagaines have a more rounded posterior margin than modern teredinids (Figs. 1E \& 1F). The extinct genus Xylophagella (Fig. 1D) has been assigned to the Xylophagainae (Turner 1969) on this criterion without evidence of presence of the dorsal accessory plate or absence of the apophysis. The extent of convergence seen within the Pholadacea can make this approach inappropriate. A possible alternative is to combine pallet and shell morphology with information provided by the morphology of the boring and its lining in order to distinguish fossil teredinids and xylophagaines. This method is particularly useful when examining wood preserved within concretions which may be serially sectioned. Using this approach the overall valve morphology is difficult to determine, but structures such as the apophysis are clearly visible.

\section{Borings and boring linings}

Borings in wood belong to the ichnogenus Teredolites. Two ichnospecies were recognised by Kelly \& Bromley (1984), an elongate form, T. longissimus (Fig. 2A), and a shorter form, T. clavatus (Fig. 2B). T. clavatus is produced by Martesiinae, such as Martesia and Opertochasma and T. longissimus by teredinids and also by xylophagaines. Whilst there is evidence to suggest that modern xylophagaines bore perpendicular to the grain of the wood (Turner 1955, Knudsen 1961), whereas modern teredinids bore parallel to the wood-grain (Turner 1966), the boring morphology alone is of little use in distinguishing between these specialist wood-boring groups.

Since the boring lining is a secretion of the mantle, hence a body fossil, it was not included by Kelly \& Bromley (1984) in their ichnotaxonomic scheme. The boring lining has been considered neither as a trace fossil nor a body fossil and thus its value in the taxonomy of fossil wood-borers has largely been overlooked. Interpretation of the lining is complex since, in Recent taxa, its extent and thickness depend on the age of the individual and environmental conditions (Turner 1966, Kelly \& Bromley 1984). Nonetheless, boring linings, which are calcite, have a high preservation potential and occur more frequently as fossils than either the delicate pallets or the aragonite valves. In some cases the tubes may be the only evidence of wood-boring, the wood and all other shelly structures having been destroyed. Fossil bivalve tubes (with or without valves preserved) have often been placed in the genus Teredo. However, to distinguish teredinids to genus or even subfamily level, pallets are needed. As a result of this inappropriate designation of tubes and valves without pallets to genus level, Bartsch (1930) proposed the informal term 'teredolithus' (unitallicized) as a repository for generically indeterminate species of shipworms.
The assumption that all lined bivalve borings in wood could be assigned to the Teredinidae was challenged by the discovery of a deep-water xylophagaine genus- Xyloredo - which secretes a calcareous lining around the posterior of the boring (Turner 1972). Nevertheless, the lining produced by modern teredinids is distinct from linings produced by pholadids like Xyloredo in two ways: (1) the siphonal (posterior) region against which the pallets are forced is thickened and may have a complex structure (Turner 1966, Huggett \& Gale 1995, Gale 1995); and (2) the boring lining may be extended around the anterior of the valves sealing the bivalve into a distally closed tube (Fig. 2A).

The possible systematic use of the thickened posterior lining in teredinids was proposed by Turner (1966) but was first included in taxonomy by Gale (1995) in his work on Tertiary fossils. Scanning electron microscope study of Recent teredinid tubes has shown that different teredinid genera produce characteristic siphonal lining structures. As the siphonal structures are intimately linked with pallets, their occurrence may be used to infer the original presence of pallets which may themselves not be preserved. The morphology of the siphonal region of the lining may also be used to identify fossil taxa to subfamily, or even genus level, which was previously impossible without pallets.

The extension of the tube around the anterior of the boring has been termed a septum (Gale 1995) or an anterior cap (Savrda \& Smith 1996). In Recent teredinids, anterior cap formation may accompany a change from cellulose digestion to filter feeding (S. M. Cragg, pers. comm. 1996). The behavioural implications of these structures in fossil teredinids have been recognized by Savrda \& Smith (1996). The bivalve may also retreat up the boring, producing secondary septa, or retrusive caps (Fig. 2B). These retrusive caps are easily recognizable in wood preserved in concretions, and are a useful tool in distinguishing fossil teredinids if applied with caution: whilst the presence of anterior and retrusive caps is strong evidence that a fossil taxon is closely related to the Teredinidae, the absence of these structures is not in itself evidence that the taxon was incapable of producing them. Preliminary studies of Cretaceous wood-borers suggest that the ability to line the anterior of the boring may have evolved some time after the ability to produce pallets.

\section{Conclusions}

The use of external valve morphology alone for the taxonomy of specialist wood-boring bivalves in the fossil record is inappropriate. The presence of an anterior boring lining or complex siphonal structures may be used, combined with shell morphology, to distinguish between wood-boring teredinids and xylo- 
phagaines. This may aid in the recognition of Cretaceous teredinid fossils where pallets are not preserved and contribute to a better understanding of the evolution of the Teredinidae from an ancestral pholad.

\section{Acknowledgements}

I thank Dr P.D. Taylor, Mr K.J. Tilbrook and Dr R.G. Bromley for constructive criticism of earlier drafts, and Dr A.S. Gale for introducing me to the wood-borers. This work was carried out whilst in receipt of a NERC grant GT4/212/93.

\section{Dansk sammendrag}

De anatomiske træk, morfologi og foring hos boringer af træborende muslinger diskuteres som grundlag for biotaxonomi.De aragonitiske skaller og paletter har et ringere bevaringspotentiale end de calcitiske foringer af boringerne, som nogle former udskiller. Foringerne kan være septate, inderholdende retrusive "hætter".

\section{References}

Cvancara, A. M. 1965: Shipworm pallets from the Paleocene (Cannonball Formation) of North Dakota. Geological Society of America Special Paper 82, 38-39.

Cvancara, A. M. 1970: Teredinid (Bivalvia) pallets from the Palaeocene of North America. Palaeontology, 13 619-622.

Elliot, G. F. 1963: A Palaeocene Teredinid (Mollusca) from Iraq. Palaeontology, 6, 315-317.

Gale, A. S. 1995 Taxonomy of London Clay (Eocene) Teredinidae (Mollusca, Bivalvia) from South East England. Proceedings of the Geologists' Association 106, 137-144.

Hoagland, K. E. \& Turner, R. D. 1981: Evolution and adaptive radiation of wood-boring bivalves (Pholadacea) Malacologia 21, 111-148.

Huggett, J. M. \& Gale, A. S. 1995: Palaeoecology and diagenesis of bored wood from the London Clay of Sheppey. Proceedings of the Geologists' Association 106, 119-136.

Kelly, S. R. A. 1988: Cretaceous wood boring bivalves from western Antarctica with review of the Mesozoic Pholadidae. Palaeontology 31, 341-372.

Kelly, S. R. A. \& Bromley, R. G. 1984: Ichnological nomenclature of clavate borings. Palaeontology 27, 793807.

Morton, B. 1983: A pallial boring gland in Barnea manilensis (Bivalvia: Pholadidae). In Morton, B. \& Dudgeon, D. (eds.) Proceedings of the Second International Workshop on the Malacofauna of Hong Kong and Southern China, pp. 191-197. Hong Kong: Hong Kong University Press.
Purchon, R. D. 1941: On the biology and relationships of the lamellibranch Xylophaga dorsalis (Turton). Journal of the Marine Biological Association of the United Kingdom 25, 1-39.

Röder, H. 1977: Zur Beziehung zwischen Konstruktion und Substrat bei mechanisch bohrenden Bohrmuscheln (Pholadidae, Teredinidae). Seckenbergiana maritima 9, 105-213.

Savrda, C..E. \& Smith, M. W. 1996: Morphological variation in Teredolites: implications for wood-boring bivalve behaviour. Paleontological Society, Special Publication 8,341 .

Turner, R. D. 1954: The family Pholadidae in the Western Atlantic and Eastern Pacific. Part 1 Pholadinae. Johnsonia $3,1-63$.

Turner, R. D. 1955: The family Pholadidae in the Western Atlantic and Eastern Pacific. Part 2 Martesiinae, Jouannetiinae and Xylophagainae. Johnsonia 3, 65-160.

Turner, R. D. 1966: A Survey and Illustrated Catalogue of the Teredinidae (Mollusca: Bivalvia). Cambridge, Massachusetts: Museum of Comparative Zoology, Harvard University.

Turner, R. D. 1967: The Xylophagainae and Teredinidae a study in contrasts. Annual Report of the American Malacological Union, 1967, 46-48.

Turner, R. D. 1969: Superfamily Pholadacea. In Moore, R.C. (ed.) Treatise on Invertebrate Paleontology, N6/2 pp. N702-N741. Geological Society of America, Boulder, Colorado and University of Kansas Press, Lawrence, Kansas.

Turner, R. D. 1972: Xyloredo, a new teredinid-like abyssal wood-borer (Mollusca, Pholadidae, Xylophagainae). Brevoria 397, 1-19.

Turner, R. D. 1973: Wood boring bivalves, opportunistic species in the deep sea. Science 180, 1377-1379.

Turner, R. D. 1977: Genetic relations of deep-sea woodborers. Bulletin of the American Malacological Union 1977, 19-25.

Turner, R. D. 1981: Forms and functions of bivalve hard substrate borers. Abstracts with Programs. Geological Society of America 13(3), 181

Waterbury, J. B., Calloway, C. B. \& Turner, R. D. 1983: A cellulolytic nitrogen-fixing bacterium cultured from the gland of Deshayes in shipworms (Bivalvia: Teredinidae). Science, 221, 1401-1403. 